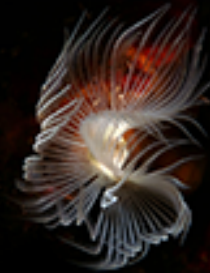

\title{
Assessing water quality in the Kelebek Stream branch (Gediz River Basin, West Anatolia of Turkey) using physicochemical and macroinvertebrate-based indices
}

\author{
Alperen ERTAŞ, Bülent YORULMAZ
}

\section{Cite this article as:}

Ertaş, A., Yorulmaz, B. (2021). Assessing water quality in the Kelebek Stream branch (Gediz River Basin, West Antolia of Turkey) using physicochemical and macroinvertebrate-based indices. Aquatic Research, 4(3), 260-278. https://doi.org/10.3153/AR21020

${ }^{1}$ Ege University, Faculty of Science, Department of Biology, 35100 Bornova, İzmir, Turkey

${ }^{2}$ Muğla Sttkı Koçman University, Faculty of Science, Department of Biology, Kötekli, Muğla, Turkey

\section{ORCID IDs of the author(s):}

A.E. 0000-0001-8510-6100

B.Y. 0000-0003-1654-8874

Submitted: 21.09 .2020

Revision requested: 05.02 .2021

Last revision received: 05.02 .2021

Accepted: 06.02.2021

Published online: 29.04 .2021

Correspondence:

Alperen ERTAŞ

E-mail: alperenertas@hotmail.com

\begin{abstract}
This study was carried out in Kelebek, which is the most important stream in Gediz River Basin, Turkey, to determine water quality by using macroinvertebrate-based metrics and physicochemial variables. In addition, we also aimed to investigate the effects of anthropogenic pressure and dam construction on stream macroinvertebrates during the study period. In this study, following biotic indices are used: Saprobi Index (SI), Biological Monitoring Working Party (BMWP), Average Score per Taxon (ASPT), Family Biotic Index (FBI), Belgian Biotic Index (BBI), as well as diversity indices: Shannon-Weaver index (SWDI), Simpsons index (SDI) and Margalef index (MDI). Collection of macroinvertebrate samples and the physicochemical measurements were carried out monthly for a year. As a result of the identification, the most dominant macroinverterate group was Insecta. Our results show the presence of 9 taxonomic group in the stream which belong to nine groups: Oligochaeta, Mollusca, Crustacea, Ephemeroptera, Plecoptera, Trichoptera, Odonata, Coleoptera, Diptera. Canonical correlation analysis (CCA) indicates importance of physicochemial variables in the distribution of different macroinvertebrates groups (total variance $88 \%$ ), species (total variance $86.2 \%$ ) and biotic indices (total variance $88.2 \%$ ). The water quality along the Kelebek Stream show variation from good class in station \#1, \#2 and \#5, to moderate in station \#3 and \#4. We conclude that BMWP (Original), BMWP (Spanish), BMWP (Greek) and ASPT indices are suitable for assessing stream health by macroinvertebrates.
\end{abstract}

Keywords: Gediz River Basin, Kelebek Stream, Macroinvertebrates, Biotic Index, Water Quality

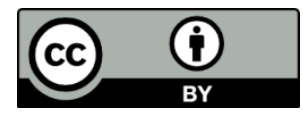

(C) 2021 The Author(s) 


\section{Introduction}

In today's world where sustainable growth and development strategies are made, the use of natural resources as a raw material and environmental pollution caused by production-consumption cause great ecological crises. Increasing damage to freshwater resources is just one of these crises. Water is an extremely valuable, economic and strategic resource both in our region and in the world. In underdeveloped and developing countries, as a result of the discharge of wastewater to water sources without treatment, 1.4 billion people in the world are still trying to continue their lives without the opportunity to use clean water (Girgin et al. 2004).

Streams cover $1 \%$ of freshwaters in the world and play a very important role in the water cycle (Wetzel, 2001). For this reason, streams must be managed well and pollution must be well detected and followed for sustainable water management. Stream polluting factors are regional and widespread pollutants such as sewage water, industrial waste, materials carried by surface runoffs, pesticides and fertilizers resulting from agricultural activities.

To determine the current status of streams, it is necessary to calculate the ecological status in the water bodies. Three basic quality elements (hydromorphological, physicochemical and biological) are used in the calculation of the ecological situation. Biological quality elements are determined using five organism groups such as benthic macroinvertebrates, macrophyte, fish, phytoplankton, and diatome (Akay et al. 2008). Among these groups, benthic macroinvertebrates get the most attention. Benthic macroinvertebrates are often preferred in water quality studies because they have a longer life cycle than macrophytes and algae, respond to environmental changes in a shorter time compared to fish. They are easy to collect and they are generally diagnosed at the level of genus and family (Bonada et al., 2006).

Biotic indices are the focus of biological monitoring studies based on benthic invertebrates. Many existing biotic indices were created according to specific geographic and climatic regions. Many European countries have created various indices with statistical variations of their diagnosis and counting on different organisms (Korycińska and Królak 2006; Yorulmaz et al. 2015). In this direction, the Saprobi Index (SI) (Kolkwitz and Marsson, 1902) in Germany, the BMWP and ASPT (De Pauw and Hawkes, 1993) in England, the BBI (De Pauw and Heylen, 2001) in Belgium, the FBI (Hilsenhoff, 1988) in USA, Danish Stream Fauna Index (DSFI) (Skriver et al., 2001) in Denmark, give the most reliable results specific to geographical regions. A lot of biotic indices have been used based on benthic macroinvertebrates to determine water quality in Anatolia (Kazanc1 and Dügel, 2000;
Kalyoncu and Zeybek, 2009; Kazanc1 et al. 2010; Zeybek et al. 2014; Yorulmaz et al. 2015; Zeybek, 2017). Biological monitoring studies are conducted for 25 years in Turkey; however a biological water quality index specific to Turkey has not been developed.

The aim of this study is to determine the water quality of the stream and to compare the results of seven biotic indices and three-diversity indices accordance with physicochemical characteristics of Kelebek Stream in West Anatolia region of Turkey.

\section{Material and Methods}

\section{Study Area and Benthic Macroinertebrate Sampling}

This study was carried out on Kelebek Stream in the Gediz River Basin of west of Turkey (Figure 1). Kelebek Stream is located in Ahmetli plain of Ahmetli district of Manisa province. The length of the stream is $41 \mathrm{~km}^{2}$. The Mediterranean climate prevails in the region. Summers are dry and hot, winters are mild and rainy. July-August are the hottest months and January-February are the coldest months.

Kelebek Stream is used as irrigation water source for the surrounding agricultural fields. The sampling stations were chosen based on stream source, dam construction, domestic areas and pollutant factors. The research was conducted during August 2019 and July 2020 at five monitoring stations that included the upstream of the stream (\#1 and \#2), and downstream (\#3, \#4 and \#5). The sampling carried out monthly over a year in the stream. The characteristic of sampling stations are presented in Table 1.

In Kelebek Stream, the benthic macroinvertebrates were collected from each station by using a classic $50 \times 30$ size with a $250 \mu \mathrm{m}$ mesh hand net. Macroinvertebrate sampling was done by moving downstream of the steam towards the upstream. Macroinvertebrates were obtained from the different substrate types such as rock, sand, and gravel present at the stations. Some sessile organisms adhering to the large stone, rock or any other substrate, collected by removing from the water was made with forceps (AQEM Consortium, 2002). The taken organisms were storage in $70 \%$ alcohol and $4 \%$ formaldehyde, and then brought to the Ege University Hydrobiology Research Laboratory. Brought samples from the stream were categorized and diagnosed to the lowest possible taxonomic level such as genus or species, under a ZEISS stereomicroscope. 


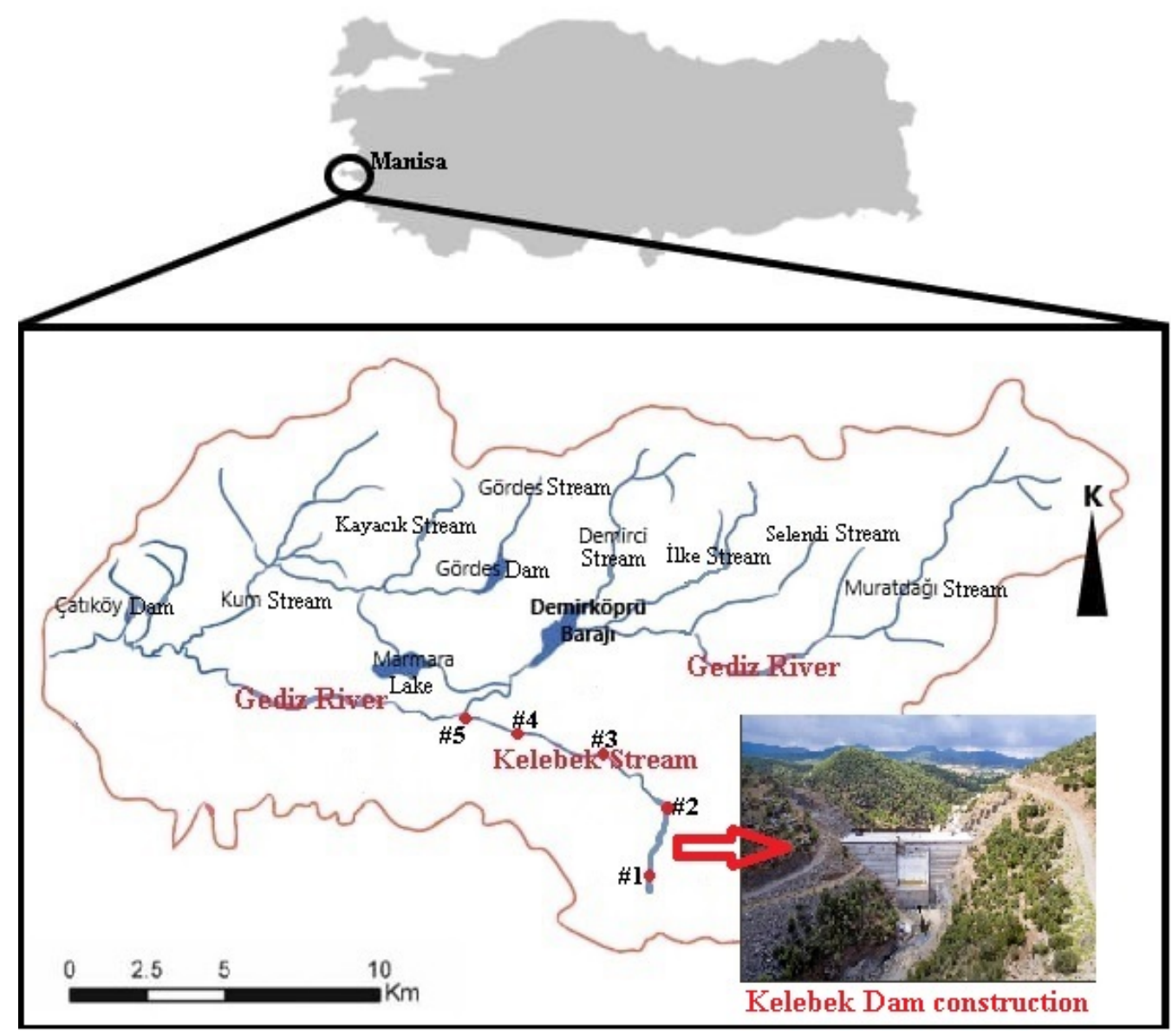

Figure 1. Map of the sampling stations in Kelebek Stream.

Table 1. Key characteristics of sampling stations in Kelebek Stream.

\begin{tabular}{|c|c|c|c|c|c|}
\hline \multicolumn{2}{|r|}{ Sampling Station } & Coordinates & Habitat & Stream morphology & Riparian vegeta- \\
\hline$\# 1$ & The source point of the stream. & $\begin{array}{l}38^{\circ} 39^{\prime} \mathrm{N} \\
27^{\circ} 90^{\prime} \mathrm{E}\end{array}$ & $\begin{array}{l}\text { Large rocks }(>50 \mathrm{~cm}) \\
\text { mixed with stone and } \\
\text { wood debris }\end{array}$ & $\begin{array}{l}\text { Flow velocity }>12 \mathrm{~m} / \mathrm{sec} \\
\text { No Macrophyte were present }\end{array}$ & $\begin{array}{l}\text { Well developed in } \\
\text { both side. }\end{array}$ \\
\hline$\# 2$ & $\begin{array}{l}\text { Kelebek Stream in village Horzum. } \\
\text { Agricultural areas and domestic } \\
\text { settlements around the stream. The } \\
\text { construction of Kelebek Dam is } \\
\text { ongoing. }\end{array}$ & $\begin{array}{l}38^{\circ} 41^{\prime} \mathrm{N} \\
27^{\circ} 92^{\prime} \mathrm{E}\end{array}$ & $\begin{array}{l}\text { Large stones, gravels } \\
\text { and wood debris. }\end{array}$ & $\begin{array}{l}\text { Flow velocity }>8 \mathrm{~m} / \mathrm{sec} \\
\text { No Macrophyte were } \\
\text { present }\end{array}$ & $\begin{array}{l}\text { Well developed in } \\
\text { both side. }\end{array}$ \\
\hline$\# 3$ & $\begin{array}{l}\text { Kelebek Stream in village Dereköy. } \\
\text { Agricultural areas and domestic } \\
\text { settlements are intense around the } \\
\text { stream. }\end{array}$ & $\begin{array}{l}38^{\circ} 47^{\prime} \mathrm{N} \\
27^{\circ} 93^{\prime} \mathrm{E}\end{array}$ & $\begin{array}{l}\text { Rubbles, gravel, silt } \\
\text { and cobbles }\end{array}$ & $\begin{array}{l}\text { Construction waste present. } \\
\text { Low water flow. Flow } \\
\text { velocity }<5 \mathrm{~m} / \mathrm{sec} \\
\text { No Macrophyte were } \\
\text { present }\end{array}$ & $\begin{array}{l}\text { It's not well } \\
\text { developed. }\end{array}$ \\
\hline$\# 4$ & $\begin{array}{l}\text { Kelebek Stream in Ahmetli district. } \\
\text { Domestic settlements are intense } \\
\text { around the stream. }\end{array}$ & $\begin{array}{l}38^{\circ} 52^{\prime} \mathrm{N} \\
27^{\circ} 94^{\prime} \mathrm{E}\end{array}$ & $\begin{array}{l}\text { Sand, rubbles, silt and } \\
\text { cobbles }\end{array}$ & $\begin{array}{l}\text { Domestic wastes runoff. } \\
\text { Flow velocity }<3 \mathrm{~m} / \mathrm{sec} \text {. No } \\
\text { Macrophyte were present }\end{array}$ & $\begin{array}{l}\text { It's not well } \\
\text { developed. }\end{array}$ \\
\hline$\# 5$ & $\begin{array}{l}\text { The point where the Kelebek Stream } \\
\text { drain into the Gediz River. }\end{array}$ & $\begin{array}{l}38^{\circ} 55^{\prime} \mathrm{N} \\
27^{\circ} 95^{\prime} \mathrm{E}\end{array}$ & Cobbles, gravels, sand & $\begin{array}{l}\text { Flow velocity } 4 \mathrm{~m} / \mathrm{sec} \text {. No } \\
\text { Macrophyte were present }\end{array}$ & $\begin{array}{l}\text { Well developed in } \\
\text { both sides. }\end{array}$ \\
\hline
\end{tabular}




\section{Physicochemical Parameters}

To determine the water quality classes, 12 physicochemical parameters were monitored over a year period. Water temperature $\left(\mathrm{T}^{\circ} \mathrm{C}\right), \mathrm{pH}$, Electrical conductivity (EC), Turbidity (TU), Oxygen saturation (Sat. $\mathrm{O}_{2}$ ) and dissolved oxygen (DO) of each water sample were measured at the sampling points by oxygen meter and multiparameter.

The Biochemical oxygen demand $\left(\mathrm{BOI}_{5}\right)$ parameter was assessed by using a spectrophotometer on the base of Winkler azide method with Merck BOD Cell Test Kits. The orthophosphate $\left(\mathrm{PO}_{4}-\mathrm{P}\right)$, ammoniacal nitrogen $\left(\mathrm{NH}_{4}-\mathrm{N}\right)$, nitrate $\left(\mathrm{NO}_{2}-\mathrm{N}\right)$, nitrite $\left(\mathrm{NO}_{3}-\mathrm{N}\right)$, and chloride $\left(\mathrm{Cl}^{-}\right)$were analysed by using appropriate Merck kits according to manufacturer's instructions (Merck Phosphate, Ammonium, Nitrite, Nitrate and Chloride Test Kits). For each analysis, two containers $(1.0 \mathrm{~L})$ were taken from the water samples in duplicate. All water samples were stored in insulated cooler containing ice and taken on the same day to laboratory and stored at $4^{\circ} \mathrm{C}$ until processing and analysis (APHA 2005).

Belong to all mathematical and statistical analyses on the physicochemical data sets were made using Excel 2019 (Mi-

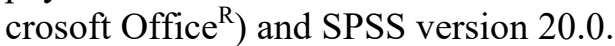

\section{Biotic Indices}

The benthic macroinvertebrates were analyzed to determine the biological quality score by using ASTERICS 4.04 software program (AQEM Consortium, 2002). With this purpose, the BBI, FBI, SI, ASPT, BMWP (Original), BMWP (Spanish) and BMWP (Greek) indices were used to determine the water quality of Kelebek Stream. The values obtained are evaluated in five classes by presenting common color code according to European Union (EU) Directive 2000/60/EC 2004-2006 (2005).

SWDI, SDI and MDI were used to determine the species richness of the stations in the stream by using the ASTERICS 4.04 software program. The faunal similarities based on benthic macroinvertebrates between the sampling stations were assessed by using Bray- Curtis similarity index (Sommerfield, 2008; Yoshioka, 2008). Pearson's based correlation analysis and multiple regression analysis were applied by using from SPSS version 20.0. In this study, the relationships between physicochemical and biotic parameters were determined by using CCA based on multivariate statistical analysis (Ter Braak, 1995).

\section{Results and Discussion}

\section{Physicochemical Variables}

The results of the analyzed physicochemical variables of water in five sampling stations along the stream are presented in Table 2. According to the One-Way Anova test, the all physicochemical parameters varied significantly with respect to the stations $(P<0.05)$.

$\mathrm{T}^{\circ} \mathrm{C}$ is a very important parameter for aquatic life. It is known that the metabolism of organisms, especially fish, varies with temperature. For example, carp is euriterm but begins feeding $\left(8-10^{\circ} \mathrm{C}\right)$ and breeding $\left(15^{\circ} \mathrm{C}\right)$ only after certain temperatures (Nikolsky, 1963). The most suitable water temperature for trouts is $8-16^{\circ} \mathrm{C}$ (Wetzel, 2001). The mean value of $\mathrm{T}^{\circ} \mathrm{C}$ varied from $9.92^{\circ} \mathrm{C}$ in station $\# 1$ in the source area, up to $15.9^{\circ} \mathrm{C}$ in station $\# 5$ of the stream.

$\mathrm{pH}$, which is an indicator of the acidity of water, is one of the important factors affecting the life. In lake waters that are not contaminated in any way, the $\mathrm{pH}$ value varies between 6.0 and 9.0. While many fish species show good growth in waters with a $\mathrm{pH}$ of 6.5-8.5 (Arrignon, 1976, Dauba, 1981), waters with a $\mathrm{pH}$ higher than 10.8 and less than 5.0 have a lethal effect for the Cyprinidae (especially carp) (Svobodá et al. 1993). Generally, alkaline waters are more suitable for trout production (Wetzel, 2001). For cyprinid health, the mandatory $\mathrm{pH}$ range in waters is expected to be $6.00-9.00$ (EC 2006). According to the $\mathrm{pH}$ data determined in the region, there is no risk for cyprinid species. The $\mathrm{pH}$ has shown small alteration, with minimum value 6.94 in station \#5 and maksimum value 7.60 in station \#1, meaning that in all stations the stream water is neutral.

The increase in EC in drinking water indicates that the water is contaminated or sea water is mixed into the water. The highest mean value of EC in this study were measured in station $\# 4(440.5 \mathrm{mS} / \mathrm{m})$ in the downstream area. It is known that $\mathrm{EC}$ values increase as the pollution increases in freshwaters (Verep et al. 2005).

TU is seen in waters containing suspended solids, which prevent the passage of light. It is recommended not to exceed 1 NTU (turbidity unit) by EPA and world health organization (WHO). The strength of the sewer and commercial waste is expressed with turbidity (Tanyolaç, 2004). Therefore, the degree of turbidity of surface water is measured as the degree of pollution. The mean value of TU concentration varied from $3.09 \mathrm{ppt}$ (station \#1) to $73.5 \mathrm{ppt}$ (station \#5).

Oxygen is a vital variable for a healthy aquatic life. It is desired that the fish grown waters are saturated with oxygen (Bremond and Vuichard, 1973). Bremond and Vuichard (1973) stated that the minimum amount of DO required for 
the cyprinid to survive should be $5.0 \mathrm{mg} / \mathrm{L}$. For trouts, the oxygen of the water should be at least $7.0 \mathrm{mg} / \mathrm{L}$ (Wetzel, 2001). $\mathrm{BOI}_{5}$ is the amount of dissolved molecular oxygen used by microorganisms during the 5-day incubation period to oxidize the structure of organic substances in water at $20^{\circ} \mathrm{C}$ (Bytyçi et al., 2019; Etemi et al., 2020). The mean value of DO concentration varied from $12.0 \mathrm{mg} / \mathrm{L}$ (station \#1) to 7.75 $\mathrm{mg} / \mathrm{L}$ (station \#5). The mean values of $\mathrm{BOI}_{5}$ in sampling stations ranged from $1.29 \mathrm{mg} / \mathrm{L}$ in station $\# 1$ to $8.76 \mathrm{mg} / \mathrm{L}$ in station \#4. The mean values of Sat. $\mathrm{O}_{2}$ in sampling stations ranged from $118.2 \%$ in station $\# 1$ to $81.7 \%$ in station $\# 5$.

Elements that limit efficiency in aquatic environments are mostly $\mathrm{PO}_{4}-\mathrm{P}, \mathrm{NH}_{4}-\mathrm{N}, \mathrm{NO}_{2}-\mathrm{N}, \mathrm{NO}_{3}-\mathrm{N}$ (Moss, 1987). The $\mathrm{NO}_{3}-\mathrm{N}$ in groundwater and surface waters results from the oxidation of ammonia, which occurs as a result of the decomposition of proteins contained in vegetable and animal wastes, and nitrate fertilizers used in agricultural areas. $\mathrm{NO}_{3}-$ $\mathrm{N}$ is the most common form of nitrogen in freshwaters, and it is very rare in uncontaminated waters (Wetzel, 2001). The $\mathrm{NO}_{3}-\mathrm{N}$ range was from $1.10 \mathrm{mg} / \mathrm{L}$ in station $\# 1$ to $6.12 \mathrm{mg} / \mathrm{L}$ in station \#4. It is also below the limit value reported as 50 $\mathrm{mg} / \mathrm{L}$ in World Health Organization, where the $\mathrm{NO}_{3}-\mathrm{N}$ values determined at all stations examined in the stream are below the recommended $10 \mathrm{mg} / \mathrm{L}$ limit value in healthy waters reported by EPA. (WHO, 2011). The increase of $\mathrm{NO}_{3}$ - in station \#4 and \#5 showed the rich of these two stations with nutrients caused by discharges of domestic wastes in the vicinity of Kelebek Stream.

Table 2. Summarize statistics of water quality parameters at the stations in Kelebek Stream.

\begin{tabular}{lcccccc}
\hline \multicolumn{2}{c}{ Parameters } & Station 1 & Station 2 & Station 3 & Station 4 & Station 5 \\
\hline $\mathrm{T}$ & $\mathrm{R}$ & $9.2-10.4$ & $9.8-11.0$ & $13.8-16.6$ & $13.9-17.1$ & $14.0-17.6$ \\
$\left({ }^{\circ} \mathrm{C}\right)$ & $\mathrm{M} \pm \mathrm{Sd}$. & $9.92 \pm 0.55$ & $10.4 \pm 0.58$ & $15.2 \pm 1.47$ & $15.6 \pm 1.63$ & $15.9 \pm 1.75$ \\
\hline $\mathrm{pH}$ & $\mathrm{R}$ & $7.51-7.73$ & $7.44-7.65$ & $7.00-7.12$ & $7.00-7.02$ & $6.87-7.00$ \\
& $\mathrm{M} \pm \mathrm{Sd}$. & $7.60 \pm 0,10$ & $7.53 \pm 0.09$ & $7.04 \pm 0.05$ & $7.00 \pm 0.009$ & $6.94 \pm 0.06$ \\
\hline $\mathrm{EC}$ & $\mathrm{R}$ & $151-173$ & $196-276$ & $228-301$ & $401-487$ & $283-369$ \\
$(\mathrm{mS} / \mathrm{m})$ & $\mathrm{M} \pm \mathrm{Sd}$. & $165.5 \pm 9.88$ & $245.7 \pm 35.7$ & $278.7 \pm 34.3$ & $440.5 \pm 35.9$ & $316.7 \pm 36.8$ \\
\hline $\mathrm{TU}$ & $\mathrm{R}$ & $2.01-3.84$ & $2.91-5.37$ & $33.7-58.1$ & $55.7-81.6$ & $60.1-84.3$ \\
$(\mathrm{ppt})$ & $\mathrm{M} \pm \mathrm{Sd}$. & $3.09 \pm 0.76$ & $4.09 \pm 1.18$ & $46.7 \pm 12.3$ & $69.2 \pm 13.6$ & $73.5 \pm 11.8$ \\
\hline $\mathrm{DO}$ & $\mathrm{R}$ & $10.4-13.8$ & $9.95-13.1$ & $9.18-9.77$ & $7.34-9.12$ & $6.90-8.79$ \\
$(\mathrm{mg} / \mathrm{l})$ & $\mathrm{M} \pm \mathrm{Sd}$. & $12.0 \pm 1.67$ & $11.5 \pm 1.70$ & $9.52 \pm 0.26$ & $8.35 \pm 0.87$ & $7.75 \pm 0.90$ \\
\hline $\mathrm{Sat.} \mathrm{O}{ }_{2}$ & $\mathrm{R}$ & $104-135$ & $96-117$ & $88-104$ & $77-100$ & $68-94$ \\
$(\%)$ & $\mathrm{M} \pm \mathrm{Sd}$. & $118.2 \pm 13.6$ & $106.5 \pm 9.67$ & $95.5 \pm 7.32$ & $88 \pm 11.6$ & $81.7 \pm 13.1$ \\
\hline $\mathrm{BOI} 5$ & $\mathrm{R}$ & $1.11-1.39$ & $1.23-1.44$ & $4.38-4.64$ & $7.19-9.78$ & $6.05-6.64$ \\
$(\mathrm{mg} / \mathrm{l})$ & $\mathrm{M} \pm \mathrm{Sd}$. & $1.29 \pm 0.12$ & $1.36 \pm 0.09$ & $4.52 \pm 0.10$ & $8.76 \pm 1.11$ & $6.32 \pm 0.25$ \\
\hline $\mathrm{NH}_{4}-\mathrm{N}$ & $\mathrm{R}$ & $0.04-0.07$ & $0.09-0.36$ & $4.37-9.76$ & $11.2-14.9$ & $9.46-11.3$ \\
$(\mathrm{mg} / \mathrm{L})$ & $\mathrm{M} \pm \mathrm{Sd}$. & $0.05 \pm 0,01$ & $0,21 \pm 0.12$ & $7.11 \pm 2.60$ & $13.4 \pm 1.57$ & $10.4 \pm 0.86$ \\
\hline $\mathrm{NO}_{2}-\mathrm{N}$ & $\mathrm{R}$ & $0.05-0.10$ & $0.09-0.12$ & $3.05-3.85$ & $4.76-5.94$ & $2.12-3.56$ \\
$(\mathrm{mg} / \mathrm{L})$ & $\mathrm{M} \pm \mathrm{Sd}$. & $0.08 \pm 0.02$ & $0.10 \pm 0.01$ & $3.29 \pm 0.37$ & $5.31 \pm 0.50$ & $3.14 \pm 0.68$ \\
\hline $\mathrm{NO}_{3}-\mathrm{N}$ & $\mathrm{R}$ & $1.07-1.13$ & $1.10-1.18$ & $2.18-2.37$ & $5.13-6.89$ & $3.81-4.78$ \\
$(\mathrm{mg} / \mathrm{L})$ & $\mathrm{M} \pm \mathrm{Sd}$. & $1.10 \pm 0.02$ & $1.14 \pm 0.03$ & $2.25 \pm 0.08$ & $6.12 \pm 0.73$ & $4.30 \pm 0.40$ \\
\hline $\mathrm{Cl}{ }^{-}$ & $\mathrm{R}$ & $2.75-3.11$ & $3.02-4.14$ & $3.78-6.37$ & $27.4-36.5$ & $19.2-25.4$ \\
$(\mathrm{mg} / \mathrm{L})$ & $\mathrm{M} \pm \mathrm{Sd}$ & $2.99 \pm 0.16$ & $3.78 \pm 0.51$ & $5.41 \pm 1.12$ & $33.1 \pm 4.16$ & $23.0 \pm 2.68$ \\
\hline $\mathrm{PO} 4$ & $\mathrm{R}$ & $0.03-0.05$ & $0.04-0.06$ & $4.26-5.11$ & $5.87-9.57$ & $3.27-6.71$ \\
$(\mathrm{mg}$ & $\mathrm{M} \pm \mathrm{Sd}$ & $0.04 \pm 0.008$ & $0.047 \pm 0.009$ & $4.89 \pm 0.42$ & $8.12 \pm 1.58$ & $5.10 \pm 1.41$ \\
$\left.\mathrm{~N}_{4} \mathrm{~L}\right)$ & & & & & & \\
\hline $\mathrm{R} \mathrm{R}_{4}$ & $\mathrm{M}$ & & & & \\
\hline
\end{tabular}

R: Range; M: Mean; Sd: Standard deviation 
$\mathrm{PO}_{4}-\mathrm{P}$ in ground and surface waters depends on population density, agricultural fertilization methods and fertilization frequency, and vegetation and soil structure are also significantly influenced by $\mathrm{PO}_{4}-\mathrm{P}$ accumulation in waters. In addition, it has been reported that detergents used in cleaning and reaching the receiving water environment with wastewater are factors affecting $\mathrm{PO}_{4}-\mathrm{P}$ concentration (Wetzel, 2001). According to the classification reported by Uslu and Türkman (1987) based on phosphate concentrations in waters; waters with phosphate concentrations up to $0.02 \mathrm{mg} / \mathrm{L}$ is Class I, waters up to $0.16 \mathrm{mg} / \mathrm{L}$ Class II, waters up to $0.65 \mathrm{mg} / \mathrm{L}$ Class III, water higher than $0.65 \mathrm{mg} / \mathrm{L}$ has class IV water quality (Wetzel, 2001). The minimum mean value of $\mathrm{PO}_{4}-\mathrm{P}$ was 0.04 $\mathrm{mg} / \mathrm{L}$, registered in stations $\# 1$, and the maximum was 8.12 $\mathrm{mg} / \mathrm{L}$ in station \#4.

According to the drinking water standards reported by the WHO, it is expected that the $\mathrm{NO}_{2}-\mathrm{N}$ value in the waters will not exceed the $0.2 \mathrm{mg} / \mathrm{L}$ limit (WHO, 2011). According to the EC directive reported by the European Commission, the $\mathrm{NO}_{2}-$ $\mathrm{N}$ concentration in waters is expected not to exceed the 0.03 $\mathrm{mg} / \mathrm{L}$ limit in terms of cyprinid health (EC, 2006). The minimum mean value of $\mathrm{NO}_{2}-\mathrm{N}$ was $0.08 \mathrm{mg} / \mathrm{L}$ in station \#1, and the maximum was $5.31 \mathrm{mg} / \mathrm{L}$ in station \#4. Accordingly, $\mathrm{NO}_{2}-\mathrm{N}$ concentrations detected downstream stations in Kelebek Stream almost pose a risk to cyprinid health. As it is known, the most important sources of $\mathrm{NO}_{2}-\mathrm{N}$ in waters are; organic substances, nitrogenous fertilizers and some minerals (Wetzel 2001). The very high nitrite values detected in the waters of the region show that the wastes of the settlements are discharged into the system without any or sufficient purification and that agricultural fertilizers used in the basin are an ecologically important source of stress.

Ammonium content increases as a result of the deterioration of organic materials, especially organic fertilizer and chemical fertilization from inorganic ammonium, discharge of domestic and industrial wastewater (Egemen and Sunlu, 1996). Tanyolaç (2004) states that ammonium nitrogen is generally below $1.0 \mathrm{mg} / \mathrm{L}$ in clean waters. The minimum mean value of $\mathrm{NH}_{4}-\mathrm{N}$ was $0.05 \mathrm{mg} / \mathrm{L}$ in station \#1, and the maximum was $13.4 \mathrm{mg} / \mathrm{L}$ in station \#4.

$\mathrm{Cl}^{-}$values are very important in terms of both drinking, industrial and irrigation water quality (Ünlü et al. 2008). The high $\mathrm{Cl}^{-}$values indicate that the electrical conductivity is also high. The amount of chloride in many drinking water does not exceed $30 \mathrm{mg} / \mathrm{L}$ (Egemen and Sunlu, 1996). The mean value of $\mathrm{Cl}(\mathrm{mg} / \mathrm{L})$ varied from $2.99 \mathrm{mg} / \mathrm{L}$ in station $\# 1$ in the source area, up to $33.1 \mathrm{mg} / \mathrm{L}$ in station $\# 4$ of the stream.

These values showed that upstream stations of the stream indicates the "good" water quality class according to Klee
(1991), but the water quality decreases in the downstream stations of the stream.

\section{Benthic Macroinvertebrate Data}

In this study, a total of 4.130 benthic macroinvertebrate samples were collected; all the specimens collected belong to nine groups: Oligochaeta, Mollusca, Crustacea, Ephemeroptera, Plecoptera, Trichoptera, Odonata, Coleoptera, Diptera. The maximum numbers of individual were collected at station \#5 (928 individuals), while the minimum numbers of individual were collected at station \#1 (711 individuals). The lowest number of individuals were determined in autumn while the highest number of individuals were determined in spring with the collection of all benthic invertebrate samples (Figure 2).

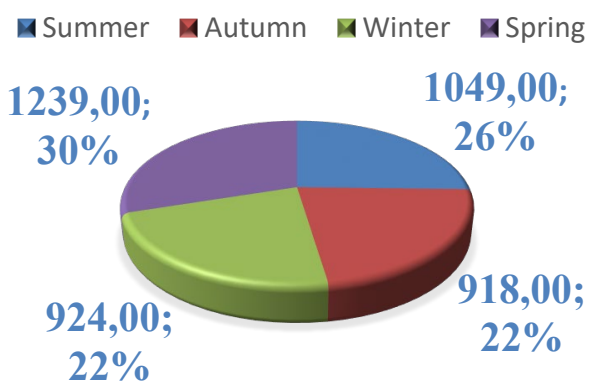

Figure 2. The total percent of benthic macroinvertebrates according to season.

As a result of this count, the most dominant group in all benthic macroinvertebrate groups was Insecta in the stream (Figure 3).

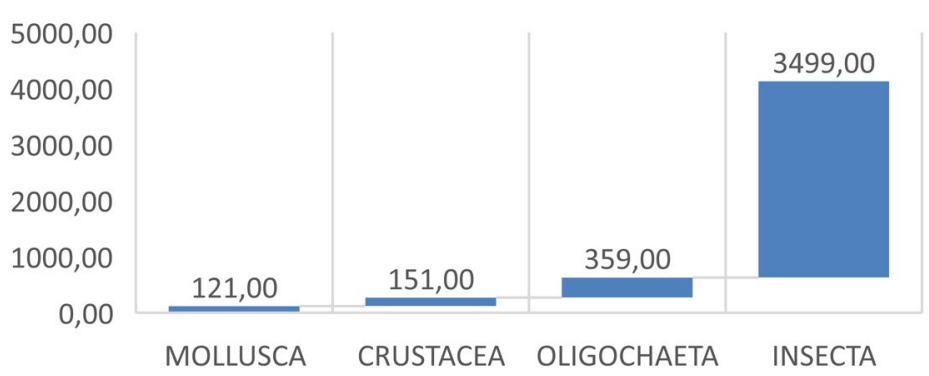

Figure 3. Benthic invertebrate groups in Kelebek Stream. Considering all taxonomic groups in the stream, Ephemeroptera is the most dominant group in station \#1, \#2 and \#5 (44\%, 34\% and 27\% respectively). Diptera is the most dominant group in station \#3 and \#4 (43\%) (Figure 4). 


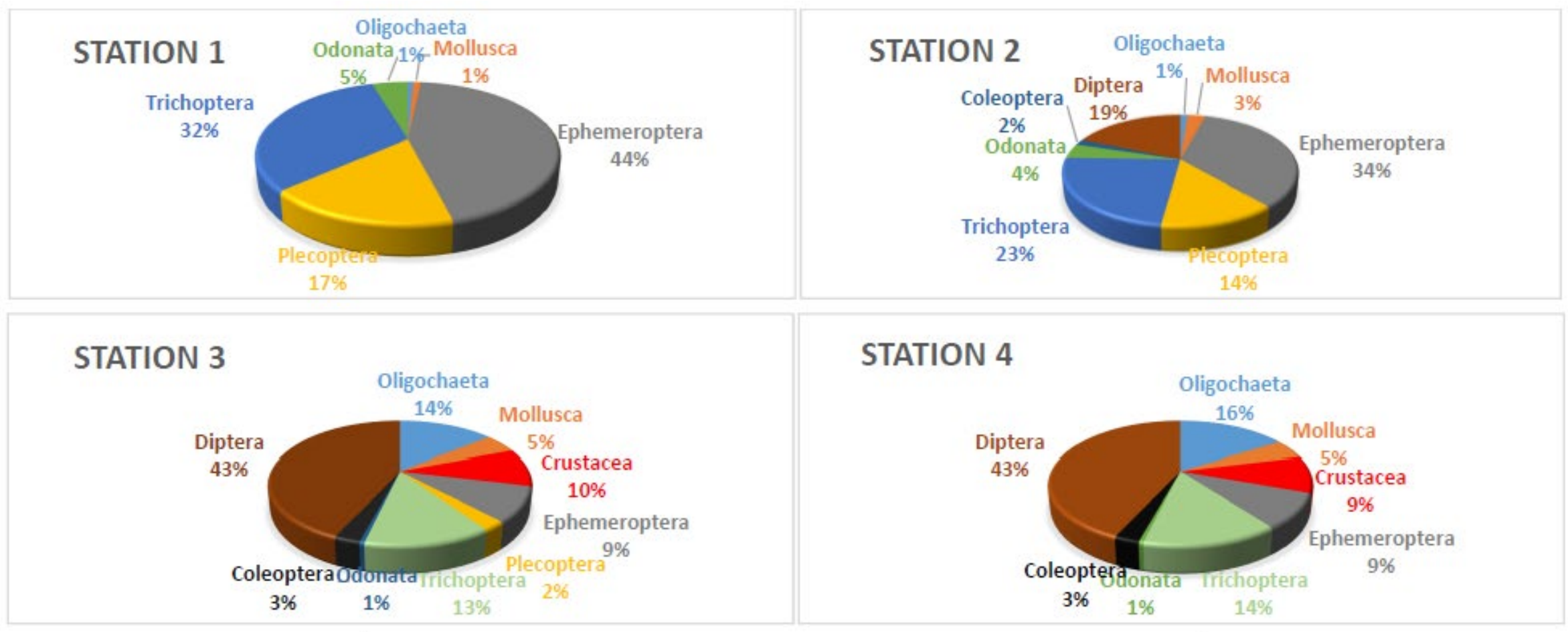

\section{STATION 5}

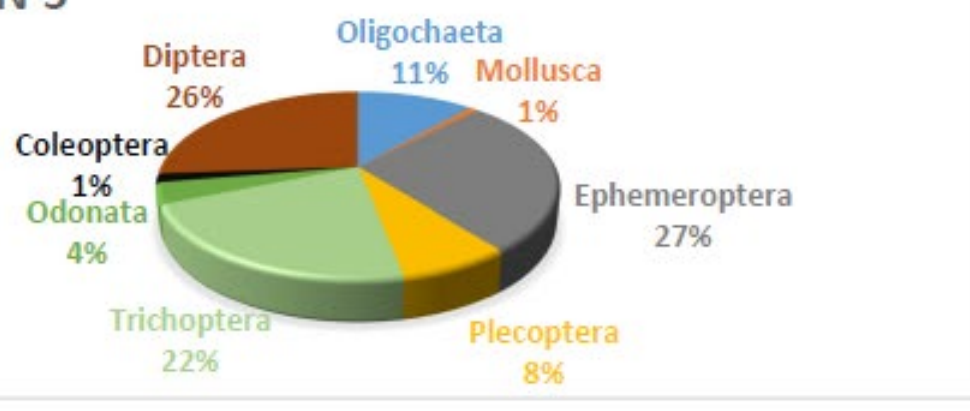

Figure 4. Dominancy (\%) of benthic macroinvertebrate orders at the stations. 
Distributions and relative percentage of occurrence (\%), along with a list of the recorded macroinvertebrates with color codes, were showed in Table 3 . The relative percentages of occurrence $(\%)$ of the determined species were differed from each other. For instance, Baetis sp. was the most dominant species $(7.454 \%, 5.698 \%)$ at the station \#1 and \#2, respectively; Gammarus sp. $(9.961 \%, 9.591 \%)$ at the station \#3 and \#4, respectively; Simulium sp. (5.585\%) at the station \#5. Gammarus sp., which belongs to the group of Amphipoda is found in low polluted river sections (Meyer, 1987). Limnodrilus species, Chironomus sp. and Chironomus tentans (Fabricius, 1805) were dominant species at the station \#3, \#4 and \#5. These species are an indicator for polysaprobic (heavy polluted) aquatic systems (Kalyoncu and Zeybek 2011; Arslan et al. 2016; Zeybek, 2017). According to Moisan and Pelletier (2008), these organisms tolerant range are high. They can find low or high DO (mg/l) concentration, Sat $\mathrm{O}_{2}$ $(\%)$ and $\mathrm{T}\left({ }^{\circ} \mathrm{C}\right)$. Existent abundant of the organic matter are favorable for benthic macroinvertebrates such as Diptera and Oligochaeta (Rashid and Pandit, 2014). Kalyoncu and Zeybek (2009) determined that the $6^{\text {th }}$ station, which is the downstream point of the stream, has low organism diversity. On the other hand, the most dominant group was Diptera followed by Oligochaeta (Tubifex tubifex). Chironomus thummi from Diptera, and Simulium sp. were the most dominant taxa in Isparta Stream.

Table 3. Distributions and relative occurrence (\%) of macrobenthic invertebrates at the stations.

\begin{tabular}{|c|c|c|c|c|c|}
\hline & $\# 1$ & $\# 2$ & $\# 3$ & $\# 4$ & $\# 5$ \\
\hline \multirow{2}{*}{\multicolumn{6}{|c|}{$\begin{array}{l}\text { OLIGOCHAETA } \\
\text { Haplotaxida }\end{array}$}} \\
\hline & & & & & \\
\hline (1) Tubifex tubifex (Muller, 1774) & - & 0.223 & 2.883 & 3.324 & 2.738 \\
\hline (2) Tubifex nerthus (Michaelsen, 1908) & - & 0.111 & 2.359 & 2.941 & 1.971 \\
\hline \multicolumn{6}{|l|}{ Naididae } \\
\hline (3) Limnodrilus hoffmeisteri (Claparede, 1862) & - & - & 2.491 & 2.685 & 2.519 \\
\hline (4) Limnodrilus udekemianus (Claparede, 1862) & - & - & 2.228 & 2.685 & 2.081 \\
\hline (5) Limnodrilus claparedianus (Ratzel, 1869) & - & - & 2.621 & 1.918 & 1.533 \\
\hline (6) Psammoryctides albicola (Michaelsen, 1901) & 0.141 & 0.111 & 1.048 & 0.895 & 0.657 \\
\hline \multicolumn{6}{|l|}{ Enchytraeidae } \\
\hline (7) Cognettia glandulosa (Michaelsen, 1888) & - & 0.558 & 0.786 & 0.767 & - \\
\hline (8) Henlea perpusilla (Friend, 1911) & 0.562 & 0.223 & - & 1.151 & - \\
\hline \multicolumn{6}{|l|}{ MOLLUSCA } \\
\hline \multicolumn{6}{|l|}{ Physidae } \\
\hline (9) Physella acuta (Draparnaud, 1805) & - & 0.782 & 1.572 & 1.662 & - \\
\hline \multicolumn{6}{|l|}{ Planorbidae } \\
\hline (10) Gyraulus albus (Muller, 1774) & - & 0.558 & 1.179 & 1.406 & - \\
\hline \multicolumn{6}{|l|}{ Lymnaeidae } \\
\hline (11) Radix labiata (Müller, 1774) & - & 0.671 & 0.917 & 0.383 & - \\
\hline \multicolumn{6}{|l|}{ Valvatidae } \\
\hline (12) Valvata piscinalis (Müller, 1774) & 0.562 & 0.558 & 0.917 & 0.639 & 0.547 \\
\hline \multicolumn{6}{|l|}{ Melanopsidae } \\
\hline (13) Melanopsis sp. & 0.421 & 0.446 & 0.524 & 1.023 & 0.328 \\
\hline \multicolumn{6}{|l|}{ CRUSTACEA } \\
\hline \multicolumn{6}{|l|}{ Gammaridae } \\
\hline (14) Gammarus sp. & - & - & 9.961 & 9.591 & - \\
\hline
\end{tabular}




\begin{tabular}{|c|c|c|c|c|c|}
\hline INSECTA & & & & & \\
\hline Ephemeroptera & & & & & \\
\hline Baetidae & & & & & \\
\hline (15) Baetis sp. & 7.454 & 5.698 & 2.752 & 2.685 & 3.504 \\
\hline (16) Baetis alpinus (Pictet, 1843) & 4.781 & 3.687 & 1.834 & 1.662 & 2.957 \\
\hline (17) Baetis muticus (Linnaeus, 1758) & 4.501 & 3.687 & 1.441 & 1.406 & 2.628 \\
\hline (18) Baetis rhodani (Pictet, 1843) & 7.454 & 5.811 & 1.965 & 1.791 & 3.943 \\
\hline Ephemeridae & & & & & \\
\hline (19) Ephemera sp. & 4.219 & 3.016 & 0.262 & 0.383 & 2.628 \\
\hline (20) Ephemera danica (Müller, 1764) & 3.797 & 2.793 & 0.131 & 0.255 & 2.519 \\
\hline Heptageniidae & & & & & \\
\hline (21) Heptagenia sp. & 4.078 & 3.798 & 0.655 & 0.639 & 3.395 \\
\hline (22) Heptagenia sulphurea (O.F. Müller, 1776) & 4.219 & 3.575 & 0.262 & 0.383 & 3.066 \\
\hline (23) Rhithrogena sp. & 3.797 & 3.128 & 0.131 & 0.127 & 3.066 \\
\hline Plecoptera & & & & & \\
\hline Perlidae & & & & & \\
\hline (24) Perla sp. & 5.485 & 4.022 & 0.655 & - & 1.971 \\
\hline (25) Perla bipunctata (Pictet, 1833) & 5.485 & 4.134 & 0.786 & - & 1.861 \\
\hline Nemouridae & & & & & \\
\hline (26) Nemoura marginata (Pictet, 1836) & 3.375 & 2.793 & 0.524 & - & 1.861 \\
\hline (27) Nemoura sp. & 3.094 & 2.905 & 0.524 & - & 1.971 \\
\hline Trichoptera & & & & & \\
\hline Glossosomatidae & & & & & \\
\hline (28) Glossosoma sp. & 3.375 & 2.905 & 2.359 & 2.557 & 3.395 \\
\hline (29) Glossosoma boltoni (Curtis 1834) & 2.390 & 1.787 & 1.703 & 1.791 & 2.301 \\
\hline (30) Glossossoma conformis (Neboiss, 1963) & 2.109 & 1.675 & 1.048 & 1.151 & 2.409 \\
\hline Hydropsychidae & & & & & \\
\hline (31) Hydropsyche sp. & 4.501 & 3.351 & 2.096 & 2.046 & 2.738 \\
\hline (32) Hydropsyche fulvipes (Curtis, 1834) & 3.516 & 2.569 & 1.179 & 1.662 & 2.519 \\
\hline (33) Hydropsyche instabilis (Curtis, 1834) & 2.672 & 1.899 & 0.655 & 0.767 & 0.657 \\
\hline Limnephilidae & & & & & \\
\hline (34) Limnephilus sp. & 2.251 & 2.011 & 1.048 & 1.023 & 1.752 \\
\hline (35) Limnephilus lunatus (Curtis, 1834) & 2.251 & 1.899 & - & - & 1.204 \\
\hline Rhyacophilidae & & & & & \\
\hline (36) Rhyacophila sp. & 3.094 & 2.458 & 1.834 & 1.662 & 1.861 \\
\hline (37) Rhyacophila isparta (Sipahiler, 1996) & 2.251 & 1.341 & 1.048 & 1.151 & 1.861 \\
\hline (38) Rhyacophila balcanica (Radovanovic 1953) & 3.516 & 1.899 & 0.524 & 0.511 & 1.314 \\
\hline Odonata & & & & & \\
\hline Aeshnidae & & & & & \\
\hline (39) Aeshna viridis (Eversmann, 1836) & 0.984 & 1.005 & - & - & 0.766 \\
\hline
\end{tabular}




\begin{tabular}{|c|c|c|c|c|c|}
\hline (40) Anax imperator (Leach 1815) & 0.984 & 0.782 & - & - & 0.985 \\
\hline \multicolumn{6}{|l|}{ Calopterygidae } \\
\hline (41) Calopteryx virgo (Linnaeus, 1758) & 0.421 & 0.446 & - & - & 0.328 \\
\hline \multicolumn{6}{|l|}{ Coenagrionidae } \\
\hline (42) Coenagrion ornatum (Selys, 1850) & 0.562 & 0.335 & - & - & 0.328 \\
\hline \multicolumn{6}{|l|}{ Gomphidae } \\
\hline (43) Onychogomphus sp. & 0.984 & 1.117 & 0.524 & 0.511 & 1.095 \\
\hline (44) Gomphus sp. & 0.703 & 0.671 & - & - & 0.219 \\
\hline \multirow{2}{*}{\multicolumn{6}{|c|}{$\begin{array}{l}\text { Coleoptera } \\
\text { Dytiscidae }\end{array}$}} \\
\hline & & & & & \\
\hline (45) Agabus bipustulatus (Linnaeus, 1767) & - & 0.893 & 1.179 & 1.151 & 0.766 \\
\hline (46) Scarodytes halensis (Fabricius, 1787) & - & 0.446 & 0.917 & 0.895 & 0.766 \\
\hline (47) Hydroporus angustatus (Sturm, 1835) & - & 0.335 & 0.655 & 0.639 & - \\
\hline \multirow{2}{*}{\multicolumn{6}{|c|}{ Diptera }} \\
\hline & & & & & \\
\hline (48) Simulium sp. & - & 3.911 & 7.339 & 7.672 & 5.585 \\
\hline (49) Simulium ornatum (Meigen, 1818) & - & 3.351 & 5.111 & 4.475 & 2.519 \\
\hline \multicolumn{6}{|l|}{ Chironomidae } \\
\hline (50) Chironomus sp. & - & 0.558 & 6.291 & 7.289 & 3.066 \\
\hline (51) Chironomus tentans (Fabricius, 1805) & - & - & 5.242 & 5.626 & 2.519 \\
\hline (52) Chironomus pallidivittatus (Edwards, 1929) & - & 0.335 & 4.062 & 4.731 & 2.519 \\
\hline (53) Synendotendipes lepidus (Meigen, 1830) & - & 1.452 & 2.752 & 2.301 & 1.861 \\
\hline (54) Polypedilum convictum (Walker, 1856) & - & 1.452 & 2.096 & 1.791 & 1.423 \\
\hline (55) Polypedilum laetum (Meigen, 1818) & - & 1.341 & 2.491 & 2.173 & 1.204 \\
\hline (56) Procladius sp. & - & 2.346 & 3.801 & 3.324 & 2.519 \\
\hline \multicolumn{6}{|l|}{ Tipulidae } \\
\hline (57) Tipula sp. & - & 2.122 & 2.621 & 2.685 & 1.752 \\
\hline \multicolumn{6}{|l|}{ Tabanidae } \\
\hline (58) Tabanus sp. & - & 2.122 & 2.359 & 1.791 & 1.642 \\
\hline
\end{tabular}

In terms of diversity, the richest was sampling station \#2 with 26 families each, 9 of them belonging to EphemeropteraPlecoptera-Trichoptera (EPT) group that are classified as sensitive organisms to the oxygen concentration in the water. The high percentage of EPT taxa indicates high water quality (Lenat, 1993). In station \#2 the most dominant within EPT were Trichoptera, with 4 families. The dominance of the orders Ephemeroptera, Plecoptera and Trichoptera which are considered to be sensitive to environmental stress signifies relatively clean conditions (Merritt, 1978). Four Diptera and Odonata, five Mollusca, three Oligochaeta an one Coleoptera families composed the rest of the macroinvertebrates in station $\# 2$. The station $\# 2$ is in the upstream of the Kelebek
Stream. According to Meyer (1987), Baetis sp. and Baetis rhodani located in the organically less polluted stream section and included in water quality "class I-II". Zeybek et al. (2014) determined most dominant taxon was Ephemeroptera (a pollution sensitive species) in upstream sampling stations in Değirmendere Stream. In the downstream stations except station \#5, the number of EPT families decreased, comparing to station \#1 and station \#2.

EPT-Taxa [\%] was one of the metrics given the best response to the physicochemical variables of water. This metrics are indicated that EPT taxa are sensitive to anthropogenic effects while Oligochaeta taxa are tolerant to anthropogenic effects in aquatic ecosystems (Ode et al. 2005). In this study, the 
highest EPT-Taxa [\%] values are obtained at the station \#1 and \#2. These stations are the upstream part of the stream and they are less affected by domestic wastes. On the contrary, the station \#3 and \#4 are downstream part of the stream. These stations are mostly affected the domestic wastes. The cause of low EPT-Taxa [\%] values at the downstream stations in stream is of the pollution that accumulates in the stream as a result of the anthropogenic activities. Other factors depend of the physical properties of the stream such as high temperature, low stream incline and reduction of stream flow.

In sampling station \#4 due to heavy pollution with dam construction and domestic waste waters, diversity of macroinvertebrates decreased and was dominated by semi tolerant and tolerant families to pollution, such as Baetidae, Chironomidae, Tubificidae, Haplotaxida, Naididae, Enchytraeidae, Tipulidae, Tabanidae and Dytiscidae. According to Hynes (1994), presence of numerous families of highly tolerant organisms usually indicates poor water quality. Due to the pollution of river water, the number of sensitive species is reduced and gradually the environmental conditions change in favor of semi tolerant and tolerant species (Zimmerman, 1993). Going downstream, in sampling station \#3, \#4 and \#5 macroinvertebrate samples consisted from Oligochaeta worms and Diptera, presented in high abundance. Oligochaeta is very common in streams and rivers. They are known as tolerant of bad or poor water quality and can tolerate heavy to extreme pollution. According to Brinkhurst and Kennedy (1965), many species of Oligochaeta are tolerant of low oxygen concentration and can live in anoxic conditions (Brinkhurst and Kennedy, 1965). Due to high tolerance to organic pollution, they are used as a good indicator species of organic pollution (Barbour, 1996).

The increased number of species in station \#2 and \#5 occured as the result of increased water level and flow velocity in this station. Due to this improvement in environmental conditions, in the station $\# 5$, the number of taxa further increased. In total 22 families were present, 9 belonging to the sensitive and semi-sensitive EPT group, and the rest consisted of semi tolerant-tolerant organisms (Dytiscidae, Physidae, Planorbidae, Valvatidae, Melanopsidae, Lymnaeidae).

\section{Biotic Index Correlations and Statistical Data Analysis}

The ecological conditions of Kelebek Stream indicate that the stream is disturbed by anthropogenic activities. The water classification in quality classes (QCs) with biotic and diversity indices is shown in Table 4. The distribution of the biotic index results according to seasons are shown by using multiple regression analysis $\left(R^{2}>0.5\right)$ in Figure 5 .

All diversity indices have shown the highest values in station $\# 2$, whereas the lowest values are registered in station \#4.
High species diversity at the upstream stations indicates unpolluted conditions whereas low species diversity in station \#3 and \#4 indicates environmental stress. The sampling station \#3 and \#4 are heavily disturbed due to dam construction and many domestic wastes discharged in this part of the stream. In these two stations, the $\mathrm{BOI}_{5}$ value is the highest, which indicates the presence of organic pollution in the water and oxygen consumption for the decomposition of organic matter. The oxygen depletion at these stations is manifested with low species diversity. Regarding the usefulness of diversity indices in the assessment of water bodies, they have been proven to be useful tools for describing the structure of the communities, but they do not indicate the pollution level of aquatic bodies. They are good for assessing organic pollution and eutrophication but poor for assessing toxicity and physical changes.

The all versions of BMWP index values were highest in station $\# 1$ and $\#$. Based on the ecological quality ratio (EQR), in these two stations, the water is classified in II quality class. The stream water quality is decreasing drastically and becomes of moderate quality (station \#2, \#3 and \#4). According to SI, the station \#1 is Oligosaprob/ Betamesosaprob-Class I-II quality class while the rest of the stations are $B e$ tamesosaprob-Class II. This index scores in Table 4 indicates that upstream of the stream, due to the distance with inhabited areas and lack of waste discharge, the water has a minimum human impact and is of high quality. Going downstream, in urban and rural areas, human activities become more intensive and impact physical and chemical parameters of the water that is manifested with moderate water quality.

Our results show that there are differences in water quality classification with different indices analyzing similar research in water quality assessment with biotic and diversity indices in other countries, we can see that some of the macroinvertebrate based indices are more sensitive and some are less sensitive to the environmental changes and it is difficult to choose which index is more reliable to be applied in stream and river quality assessment in a country (Kalyoncu and Zeybek, 2011). In our research BMWP (Original), BMWP (Spanish) and BMWP (Greek) seem to be more reliable and reflect better the environmental situation since they both are based on the presence of sensitive species to environmental variables.

In this study, the random sample cases ( $10 \%$ select case) was made on the biotic indices and physicochemical parameters to verify data sets and to determine that the data was transferred without errors in the SPSS version 20.0. Table 5 indicates the correlations of biotic and diversity indices. 
As a result of the correlation analysis, the highest positive significant correlation was found between the BMWP (Original), BMWP (Spanish) and BMWP (Greek). The SI is the negatively significant correlated with ASPT, BMWP (Original), BMWP (Spanish) and BMWP (Greek). BMWP (Greek) is the positively significant correlated with ASPT ( $r$-value
0.952, $p<0.05$ ); BMWP (Greek) is the negatively significant correlated with FBI ( $r$-value 0.952, $p<0.05$ ). ASPT is the negatively significant correlated with FBI ( $r$-value -0.970 , $p<0.01)$. However, the increase in index values of BMWP (Original), BMWP (Spanish) and BMWP (Greek) shows good ecological quality.

Table 4. Average score values and water quality classes of all indices in the stream.

\begin{tabular}{|c|c|c|c|c|c|}
\hline Metric & Station 1 & Station 2 & Station 3 & Station 4 & Station 5 \\
\hline SI & 1.751 & 1.863 & 1.883 & 1.874 & 1.784 \\
\hline Water quality class & I-II & II & II & II & II \\
\hline QCs defined by WFD & High & Good & Good & Good & Good \\
\hline BMWP (Original) & 113 & 87 & 88 & 73 & 103 \\
\hline Water quality class & II & III & III & III & II \\
\hline QCs defined by WFD & Good & Moderate & Moderate & Moderate & Good \\
\hline BMWP (Spanish) & 124 & 95 & 98 & 83 & 112 \\
\hline Water quality class & II & III & III & III & II \\
\hline QCs defined by WFD & Good & Moderate & Moderate & Moderate & Good \\
\hline BMWP (Greek) & 1174 & 921 & 912 & 767 & 1076 \\
\hline Water quality class & II & III & III & III & II \\
\hline QCs defined by WFD & Good & Moderate & Moderate & Moderate & Good \\
\hline ASPT & 6.946 & 5.722 & 5.026 & 4.812 & 6.161 \\
\hline Water quality class & I & II & II & III & I \\
\hline QCs defined by WFD & High & Good & Good & Moderate & High \\
\hline BBI & 10 & 10 & 9 & 8 & 10 \\
\hline Water quality class & I & I & I & II & I \\
\hline QCs defined by WFD & High & High & High & Good & High \\
\hline FBI & 3.25 & 4.08 & 4.91 & 5.20 & 4.21 \\
\hline Water quality class & I & II & II & II-III & I-II \\
\hline QCs defined by WFD & High & Good & Good & Moderate & High \\
\hline \multicolumn{6}{|l|}{ Diversity Indices } \\
\hline SDI & 0.962 & 0.976 & 0.964 & 0.959 & 0.972 \\
\hline SWDI & 3.528 & 3.681 & 3.574 & 3.293 & 3.684 \\
\hline MDI & 7.036 & 7.627 & 7.507 & 5.025 & 7.317 \\
\hline
\end{tabular}

Table 5. Pearson's based correlation assesment between biotic and diversity indices in the stream.

\begin{tabular}{|l|c|c|c|c|c|c|c|c|c|c|}
\hline & SI & $\begin{array}{c}\text { BMWP } \\
\text { (Original) }\end{array}$ & $\begin{array}{c}\text { BMWP } \\
\text { (Spanish) }\end{array}$ & $\begin{array}{c}\text { BMWP } \\
(\mathbf{G r e e k})\end{array}$ & ASPT & FBI & BBI & SDI & SWDI & MDI \\
\hline SI & 1 &,$- 916^{*}$ &,$- 919^{*}$ &,$- 920^{*}$ &,$- 939^{*}$ & 0,833 & $-0,648$ & 0,004 & 0,325 & 0,748 \\
\hline BMWP (Original) & & 1 &, $998^{* *}$ &, $999^{* *}$ &, $941^{*}$ & $-0,878$ & 0,801 & 0,033 & $-0,288$ & $-0,653$ \\
\hline BMWP (Spanish) & & & 1 &, $994^{* *}$ &, $933^{*}$ & $-0,866$ & 0,76 & $-0,029$ & $-0,342$ & $-0,692$ \\
\hline BMWP(Greek) & & & & 1 &, $952^{*}$ &,$- 892^{*}$ & 0,821 & 0,059 & $-0,27$ & $-0,644$ \\
\hline ASPT & & & & & 1 &,$- 970^{* *}$ & 0,823 & 0,033 & $-0,33$ & $-0,715$ \\
\hline FBI & & & & & & 1 & $-0,848$ & 0,01 & 0,375 & 0,69 \\
\hline BBI & & & & & & & 1 & 0,463 & 0,13 & $-0,227$ \\
\hline SDI & & & & & & & 1 &, $930^{*}$ & 0,65 \\
\hline SWDI & & & & & & & & 1 & 0,868 \\
\hline MDI & & & & & & & & \multicolumn{2}{c|}{1} \\
\hline
\end{tabular}

**Correlation is significant at the 0.01 level (2-tailed).

*Correlation is significant at the 0.05 level (2-tailed). 

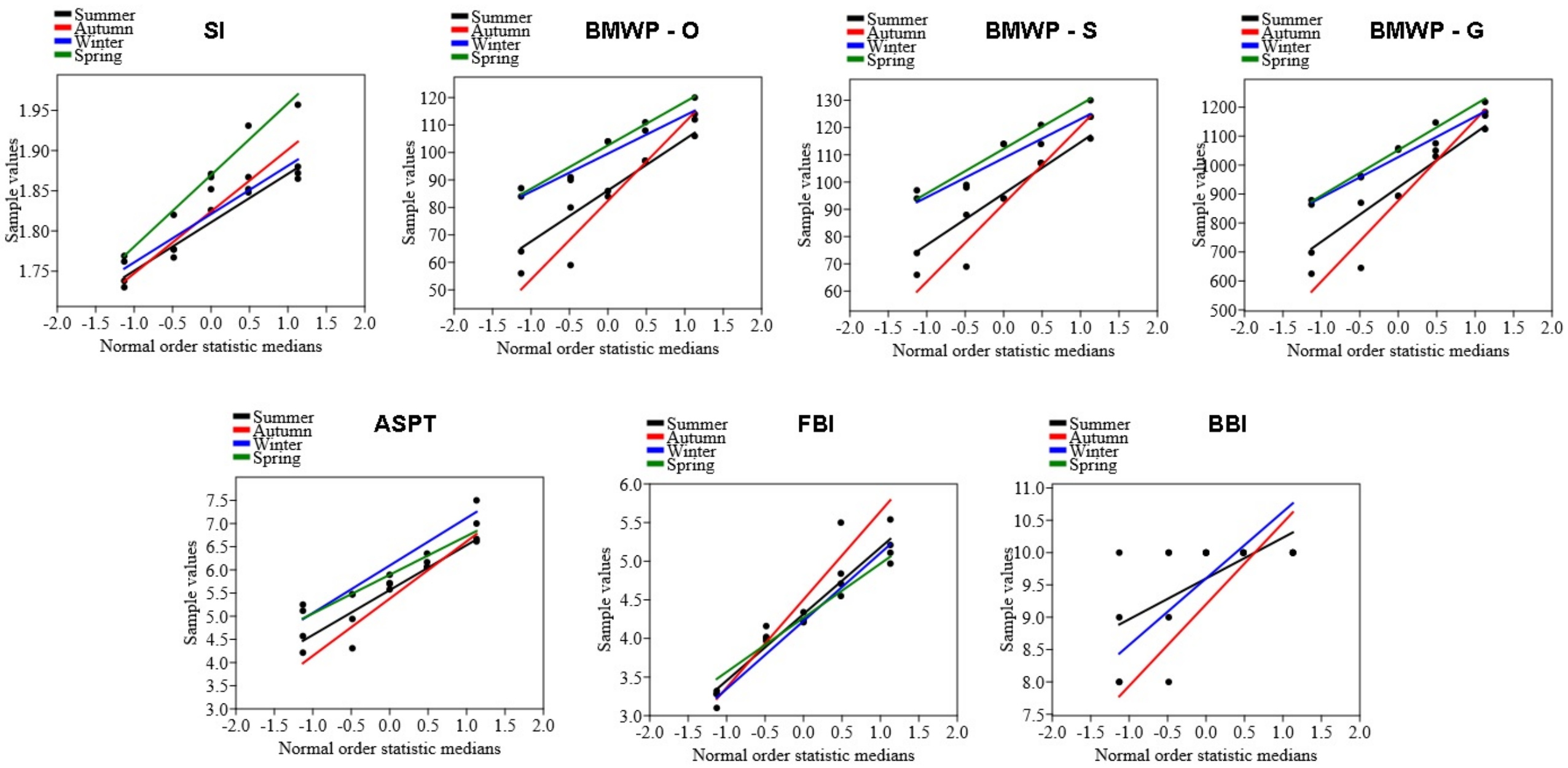

Figure 5. The distribution of the biotic index scores according to seasons in Kelebek Stream. 
In this research, CA was applied on lake parameters, to determine spatial similarity and dissimilarity for classifying of stations. The resulted dendogram (Figure 6), grouped all the five sampling stations into two statistically significant clusters, as station (station \#1-\#2) and (station \#3- \#4). On the other hand, the highest similarity was identified in the $3^{\text {rd }}$ and $4^{\text {th }}$ station while the second highest similarity was identified in the $1^{\text {st }}$ and $2^{\text {nd }}$ station.

Biotic parameters and 22 environmental variables were only used in CCA analysis according to the Kaiser-Meyer-Olkin (KMO) Sample Proficiency Test (Figure 7). The obtained results of the KMO Sample Proficiency Test were calculated as 0.793 and show that the sample size is quite good and sufficient. The CCA analysis led to the explanation total of $88 \%$ variance according to benthic macroinvertebrate orders. The distributions of EPT/OL [\%] and EPT- Taxa [\%] are positively correlated to DO, Sat. $\mathrm{O}_{2}$ and $\mathrm{pH}$. The distributions of Oligochaeta is positively correlated to $\mathrm{EC}, \mathrm{Cl}$, Turbidity, $\mathrm{BOI}_{5}, \mathrm{PO}_{4}-\mathrm{P}, \mathrm{NH}_{4}-\mathrm{N}, \mathrm{NO}_{2}-\mathrm{N}$ and $\mathrm{NO}_{3}-\mathrm{N}$ (Figure 7a). The CCA analysis led to the explanation total of $86.2 \%$ variance according to benthic macroinvertebrate species. The distributions of Simulium sp., Chironomus sp., Chironomus tentans, Tubifex tubifex and Limnodrilus species are positively correlated to $\mathrm{EC}, \mathrm{Cl}$, Turbidity, $\mathrm{BOI}_{5}, \mathrm{PO}_{4}-\mathrm{P}, \mathrm{NH}_{4}-\mathrm{N}, \mathrm{NO}_{2}-\mathrm{N}$ and $\mathrm{NO}_{3}-\mathrm{N}$ while they are negatively correlated to DO, Sat. $\mathrm{O}_{2}$ and $\mathrm{pH}$ (Figure 7b). The CCA analysis led to the explanation

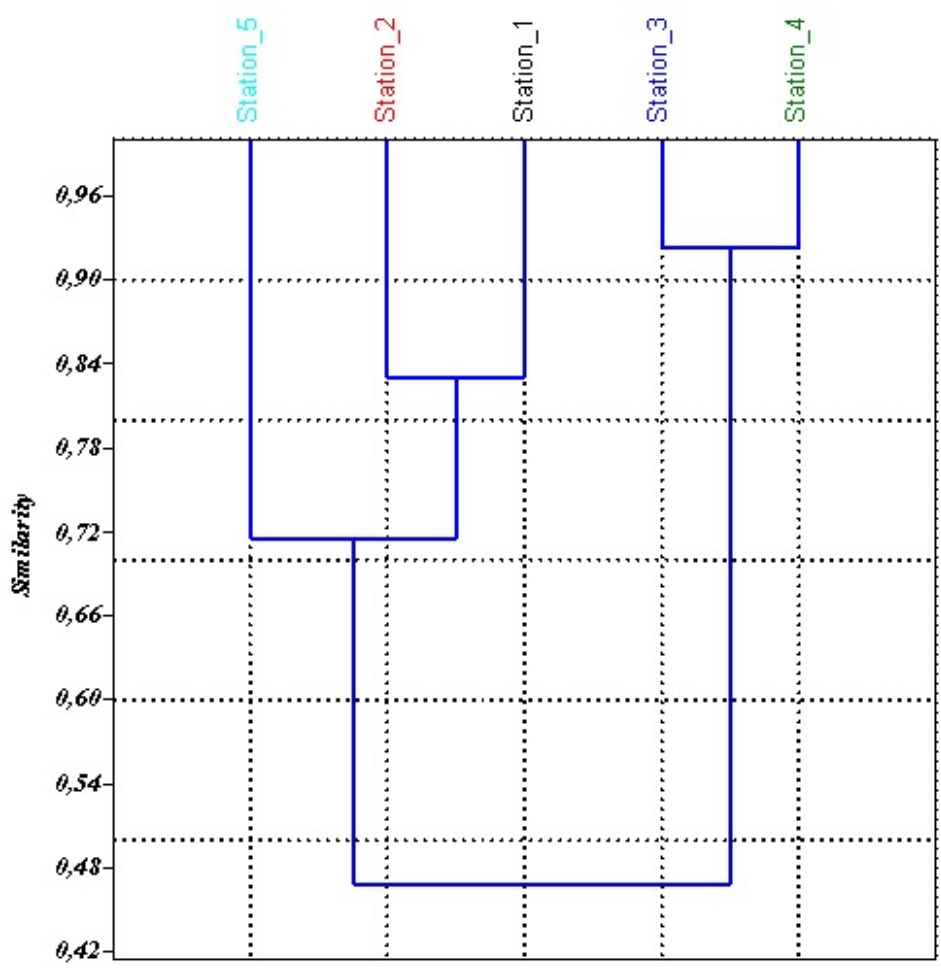

total of $88.1 \%$ variance according to biotic indices. The distributions of BMWP (Original), BMWP (Spanish), BMWP (Greek), ASPT and BBI are positively correlated to DO, Sat. $\mathrm{O} 2$ and $\mathrm{pH}$ (Figure 7c).

Kazanc1 and Dügel (2000) recorded that the BBI was in compliance with the physicochemical parameters in Yuvarlak Stream. Kantzaris et al. (2002) recorded that the BMWP, ASPT and Land Quality Indicators (LQI) were insufficient in evaluating water quality while BBI and IBE were proper. Öz and Şengörür (2004) reported that BBI was in accordance with the other indices. Kalyoncu et al. (2008) stated that the BBI and physicochemical data were more proper to evaluate the water quality. Kazanc1 et al. (2010) mentioned that the BMWP and ASPT were sufficient to evaluate water quality in Aksu Stream. Ogleni and Topal (2011) mentioned that the BMWP and ASPT were sufficient to evaluate water quality. Kalyoncu and Zeybek (2011) found that SWDI and BBI seem to be the most reliable to determine the water quality. Yorulmaz et al. (2015) applied five biotic indices and noted that the FBI was insufficient in evaluating water quality while ASPT, BMWP, SI, and BBI were appropriate. Zeybek et al. (2014) found deviations between BMWP versions. Zeybek (2017) found that the most appropriate indices for the physical and chemical indices were BMWP (original version) and ASPT (original and Czech versions).

Figure 6. Classification of stations based on similarities of in Kelebek Stream. 


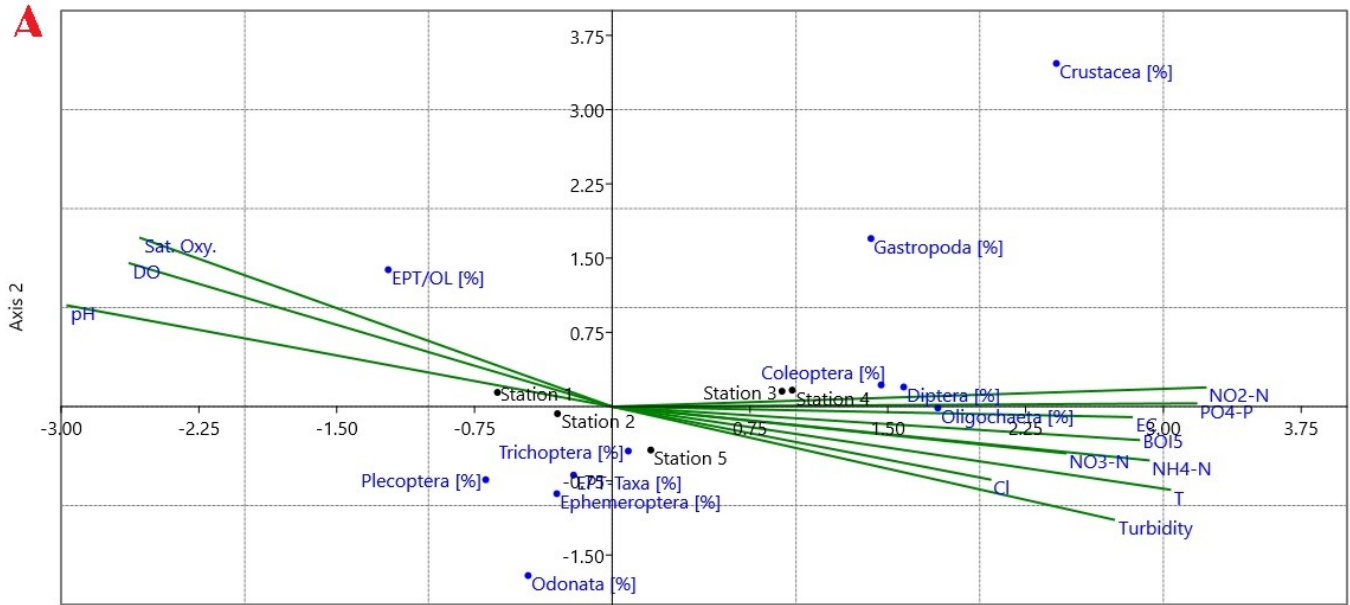

Axis 1

\section{B}

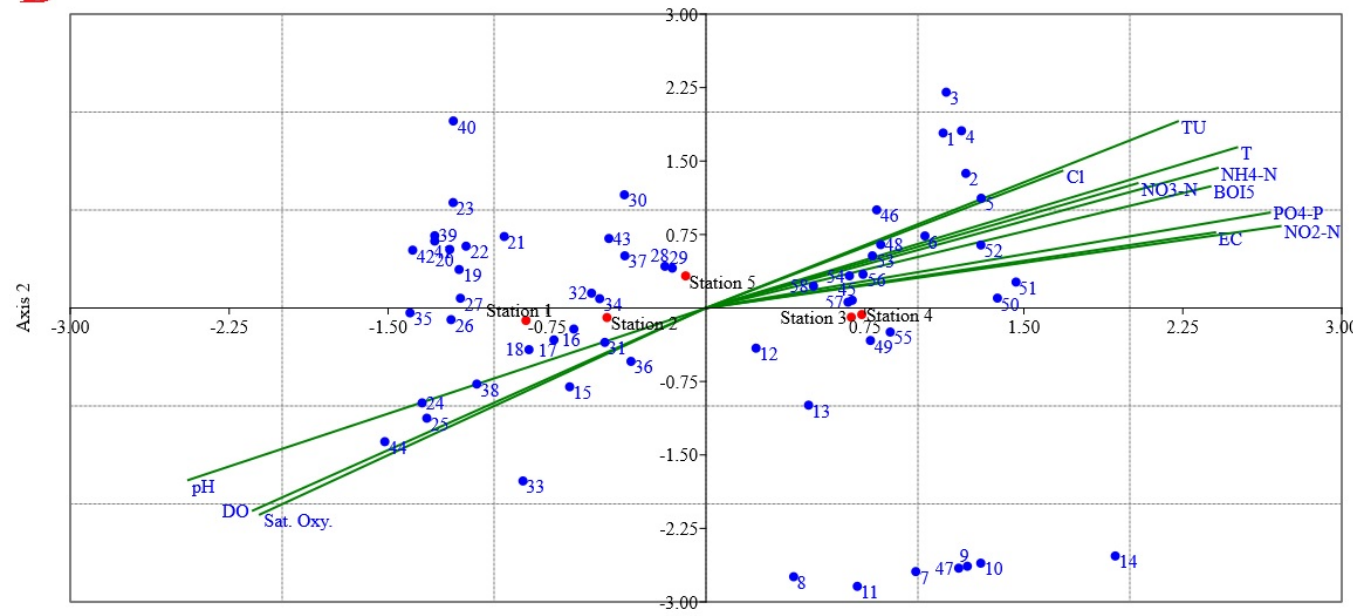

Axis 1

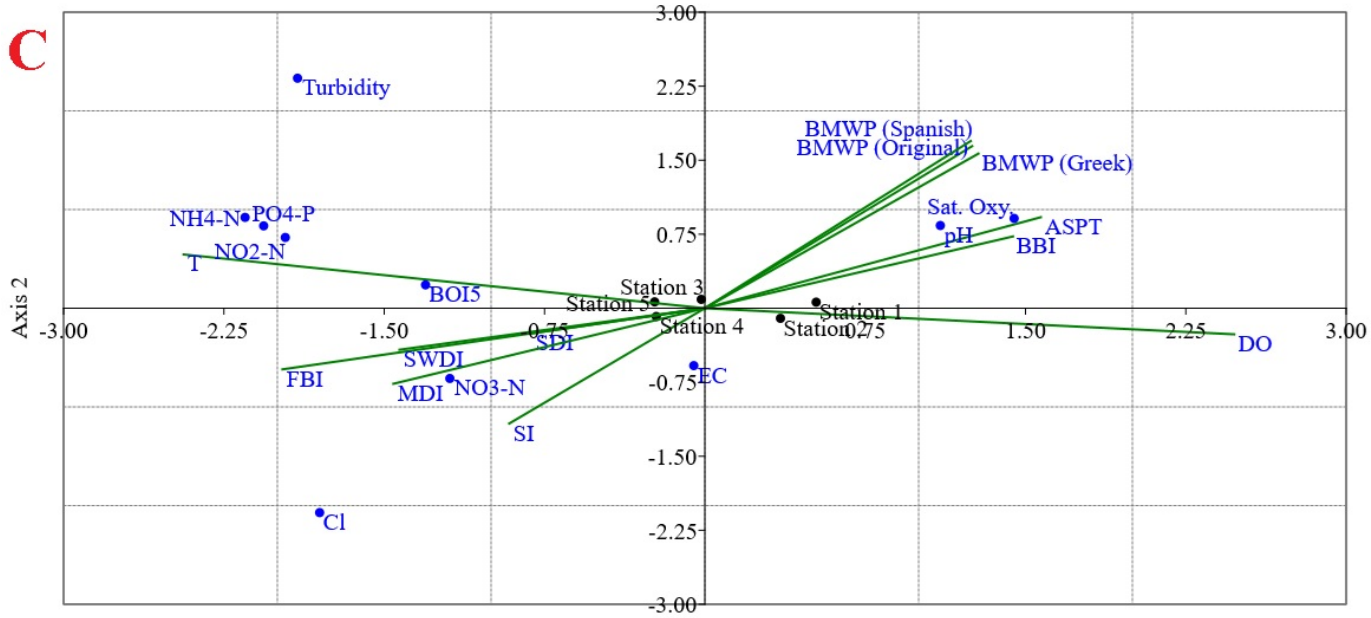

Axis 1

Figure 7. CCA plot of reference-, test-, and the most disturbed sites distributions with environmental variables. 


\section{Conclusion}

From our results, we can conclude that Kelebek Stream is disturbed by many anthropogenic activities. The main pollution sources remain the untreated wastewaters that are directly discharged into the stream, as well as industrial discharges, agricultural runoff and land use. The upstream stations of the stream are less polluted due to the distance with populated areas and farming activities, whereas in urban areas the stream is heavily polluted and this is reflected in macroinvertebrate assemblage and distribution. The increased pollution in station \#3 and \#4 caused the disappearance of sensitive species from this part of the stream and appearance of more pollution tolerant species, adapted to specific habitats. Our results have shown that the ecological status of the Kelebek Stream is moderate quality and urgent measures for the protection of Gediz River Basin and other water resources in Turkey must be implemented through professional management plans for river basins.

To improve the quality of Kelebek Stream, one of the most important branch of the Gediz River, to reduce stress and pressure on aquatic organisms and to protect the health of the local people;

- Prevention of uncontrolled discharge of debris removed during the dam construction into the stream,

- Industrial establishments located in the basin should be inspected frequently and prevented from giving their wastes to the system without treatment,

- In addition, the water quality of the stream should be monitored continuously, both physically, chemically and biologically, and should be able to intervene quickly if necessary.

We believe that this study will constitute a vital perspective to the monitoring of freshwaters in terms of data.

\section{Compliance with Ethical Standard}

Conflict of interests: The authors declare that for this article they have no actual, potential or perceived conflict of interests.

Ethics committee approval: All procedures performed in studies involving animals were in accordance with the ethical standards of the institution or practice at which the studies were conducted.

\section{Funding disclosure: -}

Acknowledgments: The authors are thankful for the support and experience to Prof Dr. Hasan KALYONCU.

Disclosure: -

\section{References}

Akay, E., Dalkıran, N., Dere, Ş. (2008). Akarsuların Biyolojik Su Kalitesinin Belirlenmesinde Bentik Makroomurgasızların Kullanımı, İklim Değişikliği ve Çevre, 3(1), 60-67.

APHA (2005). Standard methods for the examination of water and wastewater, 21st edn. American Public Health Association, Washington, DC.

Arrignon, J. (1976). Aménagement Ecologique et Piscicole des Eaux Douces, Bordas, Paris, 322 p.

Arslan, N., Salur, A., Kalyoncu, H., Mercan, D., Barışık, B., Odabaşı, D.A. (2016). The use of BMWP and ASPT indices for evaluation of water quality according to macroinvertebrates in Küçük Menderes River (Turkey). Biologia, 71(1), 49-57.

https://doi.org/10.1515/biolog-2016-0005

AQEM Consortium (2002). The AQEM sampling method to be applied in STAR. Chapters 7-8. http://www.eustar.at/pdf/AqemMacroinvertebrateSamplingProtocol.pdf

(accessed 16.07.2020)

Barbour, M., Gerritsen, J., Griffith, G., Frydenborg, R., McCarron, E., White, J., Bastian, M. (1996). A Framework for Biological Criteria for Florida Streams Using Benthic Macroinvertebrates. Journal of the North American Benthological Society, 15(2), 185-211.

https://doi.org/10.2307/1467948.

Bonada, N., Rieradevall, M., Prat, N., Resh, V.H. (2006). Benthic macroinvertebrate assemblages and macrohabitat connectivity in Mediterranean-Climate streams of Northern California. Journal of The North American Benthological Society, 25(1), 32-43.

https://doi.org/10.1899/0887-

3593(2006)25[32:BMAAMC]2.0.CO;2

Bremond, R., Vuichard, R. (1973). Parameters de la qualite des eaux: Ministere de la Protection de la Nature et de Environnement, Documentation, Française, Paris, 179 p.

Brinkhurst, R., Kennedy, C. (1965). Studies on the Biology of theTubificidae (Annelida, Oligochaeta) in a Polluted Stream. Journal of Animal Ecology, 34(2), 429-443. https://doi.org/10.2307/2659.

Bytyqi, P., Ymeri, P., Czikkely, M., Fetoshi, O., Shala-Abazi, A., Ismaili, M., Ramshaj, Q., Millaku, F. (2019). The Application of Benthic Diatoms in Water Quality Assessment 
in Lepenci River Basin, Kosovo. Journal of Ecological Engineering, 20(11), 43-57.

https://doi.org/10.12911/22998993/113409

De Pauw, N., Hawkes, H.A. (1993). Biological Monitoring of River Water Quality. in: Walley, W.J., Judd, S. (Eds.), River Water Quality Monitoring and Control. Aston University, Birmingham, 87-112. ISSN: 1-85449-115-6.

De Pauw, N., Heylen, S. (2001). Biotic index for sediment quality assessment of watercourses in Flanders, Belgium. Aquatic Ecology, 35, 121-133.

https://doi.org/10.1023/A:1011478427152.

EC (European Communities) (2006). EC of the European Parliament and of the council of 6 September 2006 on the quality of fresh waters needing protection or improvement in order to support fish life. Directive 2006/44. https://eurlex.europa.eu/LexUriServ/LexUri-

Serv.do?uri=OJ:L:2006:264:0020:0031:EN:PDF

Egemen, Ö., Sunlu, U. (1996). Water Quality (Second Edition) (in Turkish). İzmir: Ege University Press. ISBN: 9757572-60-8

Etemi, F. Z., Bytyqi, P., Ismaili, M., Fetoshi, O., Ymeri, P., Shala-Abazi, A., Muja-Bajraktari, N., Czikkely, M. (2020). The use of macroinvertebrate based biotic indices and diversity indices to evaluate the water quality of Lepenci river basin in Kosovo. Journal of Environmental Science and Health, Part A, 55(6), 748-758.

https://doi.org/10.1080/10934529.2020.1738172

EU Directive 2000/60/EC 2004-2006 (2005). Common Implementation Strategy for the Water Framework Directive (2000/60/EC). Guidance on the Intercalibration Process 2004-2006; Office for Official Publications of the European Communities: Luxembourg, 2005, Vol. 1; p. 31.

Girgin, S., Akyürek, Z., Usul, N. (2004). Türkiye için Coğrafi Bilgi Sistemleri Tabanlı Su kalitesi Veri Analiz Sistemi Geliştirilmesi, 3.Coğrafi Bilgi Sistemleri Bilişim Günleri, 231-247.

Hilsenhoff, W.L. (1988). Rapid field assessment of organic pollution with a family-level biotic index. Journal of the North American Benthological Society, 7(1), 65-68.

https://doi.org/10.2307/1467832
Hynes, H. (1994). Historical Perspective and Future Direction of Biological Monitoring of Aquatic Systems. In: Biological Monitoring of Aquatic Systems; Loeb, S. L., Spacie, A., Eds.; Lewis Publishers: Boca Raton, p. 11-22.

Kalyoncu, H., Yorulmaz, B., Barlas, M., Yıldırım, M. Z., Zeybek, M. (2008). Aksu Çayı'nın su kalitesi ve fizikokimyasal parametrelerin makroomurgasız çeşitliliği üzerine etkisi. Fırat Üniversitesi Fen ve Mühendislik Bilimleri Dergisi, 20(1), 23-33.

Kalyoncu, H., Zeybek, M. (2009). Benthic fauna of Ağlasun and Isparta streams and determination of water quality according to physicochemical parameters and Belgium Biotic Index. Biyoloji Bilimleri Araştırma Dergisi, 2 (1), 41-48.

Kalyoncu, H., Zeybek, M. (2011). An application of different biotic and diversity indices for assessing water quality: A case study in the Rivers Çukurca and Isparta (Turkey). African Journal of Agricultural Research, 6(1), 19-27.

Kantzaris, V., Iliopoulou- Georgudaki, J., Katharios, P., Kaspiris, P. (2002). A Comparison of Several Biotic Indices Used For Water Quality Assessment at The Greek Rivers. Fresenius Environmental Bulletin, 11(11), 1000-1007.

Kazancı, N., Dügel, M. (2000). An evulation of water quality of Yuvarlakçay stream in the Köycegiz-Dalyan protected area South- Western Turkey. Turkish Journal of Zoology, 24, 69-80.

Kazancı, N., Ekingen, P., Türkmen, G., Ertunç, Ö., Dügel, M., Gültutan, Y. (2010). Assesment of ecological quality of Aksu Stream (Giresun, Turkey) in Eastern Black Sea Region by using Water Framework Directive (WFD) methods based on benthic macroinvertebrates. Review of Hydrobiology, $3(2), 165-184$.

Kazi, T.G., Arain, M.B., Jamali, M.K., Jalbani, N., Afridi, H.I., Sarfraz, R.A., Baig, J.A., Shah, A.Q. (2009). Assessment of water quality of polluted lake using multivariate statistical techniques: A case study. Ecotoxicology and Environmental Safety, 72(2), 301-309.

https://doi.org/10.1016/j.ecoenv.2008.02.024.

Klee, O. (1991). Angewandte Hydrobiologie.- G. Theieme Verlag, 2. neubearbeitete und erweiterte Auflage, 272, Stuttgart-New York.

Kolkwitz, R., Marsson, M. (1902). Grundsätze für die biologische Beurteilung des Wassers nach seiner Flora und 
Fauna. Mitt. Prüfungsanst. Wasserversorgung. Abwasserreing. 1, 33-72.

Korycińska, M., Królak, E. (2006). The use of various biotic indices for evaluationof water quality in the Lowland rivers of Poland (Exemplified by the Liwiec river). Polish Journal of Environmental Studies, 15(3), 419-428.

Lenat, D. (1993). Freshwater Biomonitoring and Benthic Macroinvertebrates. Journal of the North American Benthological Society, 12, 220-222.

https://doi.org/10.2307/1467358

Merritt, R., Cummins, K., Berg, M. (1978). An Introduction to the Aquatic Insects of North America, 1st ed.; Kendall/Hunt Publishing Company: Dubuque, Iowa, U.S.A.

Meyer, D. (1987). Makroskopisch- Biologische Feldmethoden zur Wassergütebeurteilung von Fliegewässern, 3. Auflage, A.L.G., 6, 3000, Hannover, 140p.

Moisan, J., Pelletier, L. (2008). Guide de surveillance biologique basée sur les macroinvertébrés benthiques d'eau douce du Québec-cours d'eau peu profonde à substrat grossier. Direction de Suivi de l'Etat de l'Environnement, Ministère du Développement Durable de l'Environnement et des Parcs.

Moss, D., Furse, M.T., Wright, J.F., Armitage, P.D. (1987). The prediction of the macro-invertebrate fauna of unpol- luted running-water sites in Great Britain using environmental data. Freshwater Biology, 17, 41-52.

https://doi.org/10.1111/j.1365-2427.1987.tb01027.x

Nikolsky, G.V. (1963). The Ecology of Fishes (Translated by L. Birkett), Academic Press, London and New York, 352 p.

Ode, P.R., Rehn, A.C., May, J.T. (2005). A quantitative tool for assessing the integrity of southern coastal California streams. Environmental Management, 35, 493-504.

https://doi.org/10.1007/s00267-004-0035-8.

Ogleni, N., Topal, B. (2011). Water quality assessment of the Mudurnu river (Turkey), using biotic indices. Water Resources Managemant, 25, 2487-2508.

https://doi.org/10.1007/s11269-011-9822-1

Öz, N., Sengörür, B. (2004). the determining of water quality with biotic indices in the Melen river and its tributaries. Fresenius Environmental Bulletin, 13(1), 69-70.
Rashid, R., Pandit, A. K., (2014). Macroinvertebrates (Oligochaetes) as indicators of pollution: A review. Journal of Ecology and the Natural Environment, 6(4), 140-144. https://doi.org/10.5897/JENE2014.0443

Skriver, J., Friberg, N., Kirkegaard, J. (2001). Biological assessment of watercourse quality in Denmark: Introduction of the Danish Stream Fauna Index (DSFI) as the official biomonitoring method. Verhandlungen des Internationalen Verein Limnologie, 27, 1822-1830.

https://doi.org/10.1080/03680770.1998.11901556

Somerfield, P.J. (2008). Identification of the Bray-Curtis similarity index: Comment on Yoshioka (2008). Marine Ecology Progress Series, 372, 303-306.

https://doi.org/10.3354/meps07841.

Svobodá, Z., Lloyd, R., Máchová, J., Vykusová, B. (1993). Water quality and fish health, FAO, EIFAC technical paper, No:54.

Tanyolac, J. (2004). Limnology (3rd edition) (in Turkish), Ankara: Hatipoğlu Press. ISBN: 975-752-746-6

Ter Braak, C.J.F. (1995). Ordination. In: Jongman RHG, ter Braak CJF, Van Tongeren OFR, editors. Data Analysis in Community and Landscape Ecology. Cambridge, UK: Cambridge University Press, pp. 91-173.

https://doi.org/10.1017/CBO9780511525575.007

Uslu, O., Türkman, A. (1987). Su kirliliği ve kontrolü. Ankara: T.C. Başbakanlık Çevre Genel Müdürlüğü Yayınları 398 s.

Ünlü, A., Çoban, F., Tunç, S. (2008). Investigation of Lake Hazar Water Quality According to physical and inorganic chemical parameters (in Turkish with English abstract). Journal of The Faculty of Engineeering and Architecture of Gazi University, 23(1), 119-127.

Wetzel, R.G. (2001). Limnology Lake and Reservoir Ecosystems. Academic Press, San Diego. Third Edition. Academic Press, San Diego. https://doi.org/10.1016/C2009-002112-6

WHO (World Heath Organization) (2011). Guidelines for drinking-water quality. World Heath Organization Library Cataloguing-in-Publication Data, NLM classification: WA 675. ISBN: 9789241548151 
Verep, B., Serdar, O., Turan, D., Şahin, C. (2005). Determination of water quality in terms of physico-chemical structure of the river Iyidere (Trabzon). Ecology, 14(57), 26-35.

Yorulmaz, B., Sukatar, A., Barlas, M. (2015). Comparative analysis of biotic indices for evaluation of water quality of Esen river in South-West anatolia, Turkey. Fresenius Enviromental Bulletin, 24(1a), 188-194

Yoshioka, P.M. (2008). Misidentification of the Bray-Curtis similarity index. Marine Ecology Progress Series, 368, 309310.

https://doi.org/10.3354/meps07728

Zeybek, M., Kalyoncu, H., Karakuş, B., Özgül, S. (2014). The use of BMWP and ASPT indices for evaluation of water quality according to macroinvertebrates in Değirmendere
Stream (Isparta, Turkey). Turkish Journal of Zoology, 38, 603-613.

https://doi.org/10.3906/zoo-1310-9

Zeybek, M. (2017). Macroinvertebrate-based biotic indices for evaluating the water quality of Karg1 Stream (Antalya, Turkey). Turkish Journal of Zoology, 41, 476-486.

https://doi.org/10.3906/zoo-1602-10

Zimmerman, M. (1993). The Use of the Biotic Index as an Indication of Water Quality. In Tested Studies for Laboratory Teaching. Proceedings of the 5th Workshop/Conference of the Journal of Environmental Science and Health, Parta 757 Association for Biology Laboratory Education (ABLE); Goldman, C.A., Hauta P.L., O'Donnell, M.A., Andrews S.E., \& van der Heiden R., Vol. 5, pp.85-98. 